\title{
Use of palm oil cake in diets for slow growing chickens
}

\section{[Utilização da torta de palmiste em dietas para frangos de corte de crescimento lento]}

\section{"Scientific Article /Artigo Científico"}

\section{Janaína de Cássia Braga Arruda ${ }^{1 *}$, Lívia Anália Bentes da Fonseca², Yan Mathews Leray Barata², Brenda Kelly Viana Leite ${ }^{2}$, Maria Cristina Manno ${ }^{2}$, Kedson Raul de Souza Lima ${ }^{2}$}

\author{
${ }^{1}$ Programa de Pós-Graduação em Saúde e Produção Animal na Amazônia, Universidade Federal Rural da Amazônia, \\ Belém-PA, Brasil. \\ ${ }^{2}$ Instituto da Saúde e Produção Animal, Universidade Federal Rural da Amazônia, Belém-PA, Brasil \\ *Autor para correspondência/Corresponding author: E-mail: jcb.arruda@gmail.com
}

\begin{abstract}
Looking for food alternatives for slow-growing broiler chickens is a necessity to boost production, which is mainly conducted by small and medium producers linked to family farming, especially in the Amazon region. For this reason, the objective was to evaluate the potential use of Palm Oil Cake (POC) as an alternative ingredient in the feeding of slow-growing broiler chickens up to 28 days of age. We used 416 male French Red-Naked Neck chicks, in a completely randomized experimental design with four treatments $(0,10,15$, and $20 \%$ of POC inclusion) with eight replicates each. The performance of the birds, allometry of the digestive organs and the economic analysis of the diets were evaluated. It is concluded that POC can be included in the diets of slow growing broiler chickens, up to 28 days, in up to $15 \%$ without causing damage in their performance, without negatively modifying the allometry of the digestive organs and without economic disadvantages to the producer.
\end{abstract}

Keywords: alternative feeding; agro-industrial by-product; palm kernel cake; country chicken.

\section{Resumo}

Buscar alternativas alimentares para a criação de frango de corte de crescimento lento é uma necessidade para impulsionar a produção, que é conduzida majoritariamente por pequenos e médios produtores ligados à agricultura familiar, principalmente na região amazônica. Desta forma, objetivou-se avaliar o potencial de utilização da Torta de Palmiste (TP) como ingrediente alternativo na alimentação de frango de corte de crescimento lento até 28 dias de idade. Utilizamos 416 pintos machos, da linhagem Frances Pescoço Pelado Vermelho, em um delineamento experimental inteiramente casualisado com quatro tratamentos $(0,10,15 \mathrm{e}$ $20 \%$ de inclusão de TP) de oito repetições cada. Foi avaliado o desempenho das aves, alometria dos órgãos digestivos e realizada a análise econômica das dietas. Conclui-se que a TP pode ser incluída nas rações de frango de corte de crescimento lento, até 28 dias, em até 15\% sem ocasionar prejuízo no seu desempenho, sem modificar negativamente a alometria dos órgãos digestivos e sem desvantagens econômicas ao produtor.

Palavras-chaves: alimentação alternativa; frango caipira; subproduto agroindustrial; torta de dendê.

\section{Introduction}

The slow-growing broiler chicken, commonly called "free-range chicken" was one of the options that emerged in recent decades as a differentiated proposal for consumers concerned with health, food safety, the environment, sustainable ecology and a different meat (Zanusso and Dionello, 2003; Braga and Roque, 2008; Guéguen and Pascal, 2010). Even companies that use the conventional rearing system for broilers are going through changes to follow this consumer market trend (Brum et al., 2010).

Slow growing chickens show growth rates and curves different than conventional lineage of 
fast growing chickens; as well as low genetic potential of growth, high rusticity, and good adaptability (Albino et al., 2005). This growth rate defines the meat quality parameters such as tenderness, marbling, and color. However, not a lot is known about its nutritional requirements, about its fat deposition, and intramuscular mass (Nahashon et al., 2010). These birds allow some adaptations in the breeding system, due to the great rusticity and resistance when compared to the fast growing industrial chicken; one of the striking aspects associated with this system is the fact that birds can feed on alternative products without prejudice to their performance (Santos and Granjeiro, 2012). The traditional raw materials used in the formulation of feed, such as corn and soybeans, for example, reach very high prices in the national and international market, especially in the off-season, the search for alternative foods is essential, especially those of origin in the industry and regional trade, with the main objective of cheapening the production cost of the rations and meeting the nutritional requirements of the birds (Camelo et al., 2015)

When using alternative sources of food, economic analysis is essential for the functioning of the productive system, as a determining factor in the decision to use or not to use alternative ingredients in poultry feed (Fernandes et al., 2012). Nunes et al. (2013) state that research with agro-industrial waste was carried out to determine the best options for alternative sources of feed, which in addition to providing good performance to animals, also decrease the cost of feed, resulting in greater profitability for the producer. The inclusion of oil sources in animal feed seems to be a viable alternative (Correia et al., 2011), mainly due to the high content of protein and ether extract, which characterize them as a protein/energy nutrient, being able to meet these nutritional requirements of the animals (Santos et al., 2012).

Palm oil cake (POC), also called palm kernel cake, is the by-product of palm oil extraction from oil palm (Elaeis guineenses), has a stable worldwide demand and in addition to the food industry, has been used for the production of (Sousa et al., 2010). Some factors lead palm kernel oil to be considered a very competitive byproduct in animal feed (Bringel et al., 2011; Nunes et al., 2011), among them: good amount of residual oil (Noel, 2003), potentially cheaper food source, lack of anti-nutritional factors, and its protein content (12-19\%), ether extract (3-20\%), and crude fiber content (14-21\%). In ruminant nutrition, several researches were developed with the objective of predicting the best level of inclusion and replacement of palm oil cake and its effect on the performance of these animals (Silva et al., 2005; Cunha et al., 2012).

Currently, there is a vast literature on its use in the nutrition of several species, however, for slow growing chickens; there are still just a few studies on the use of palm oil cake in the feeding of those birds (Sousa et al., 2010).

The aim of this study was to evaluate slow growing chickens over the starter phase (1-28 days), fed with feed that had different levels of inclusion of palm oil cake (POC) as alternative feed, through the performance of the birds, the allometry of the digestive organs of the birds, and economic analysis of the diets.

\section{Materials and Methods}

\section{Location of the Study}

The study was conducted in a poultry research house unit located in the Poultry Sector of the Institute of Health and Animal Production at the Universidade Federal Rural da Amazônia, Belém (ISPA/UFRA - Belém).

\section{Housing}

A total of 416 one-day old male naked neck chicks were procured from a local hatchery; they were vaccinated against Marek's disease, New Castle, bronchitis, and Gumboro's disease. Thirteen birds were housed in a $2.5 \mathrm{~m}^{2}$ experimental box; final density was 5.2 birds $/ \mathrm{m}^{2}$. One supplemental lamp heat source $(250 \mathrm{w})$ was provided per experimental box from arrival to day 12. The lighting program was $24 \mathrm{~L}: 0 \mathrm{D}$, chicks were maintained on natural light during the day and on continuous artificial light at night.

The birds were fed an iso-nitrogenous, isovitamin, and iso-mineral ration, calculated according to Rostagno et al. (2011), adapted from fast growing male chickens (nutritional requirements from 22-33 days) for slow growing chickens (considering one phase from 1-28 days) to meet the nutritional requirements. Not exceeded the nutritional values reported in Table 1. 


\section{Experimental design and diets}

A completely randomized design was used with eight replicate pens of 13 chickens assigned to each of four dietary treatments. The starter phase was over when birds were 28 days old. The dietary treatments were: T0: Control ration; T1: Ration with inclusion of $10 \%$ of palm oil cake; T2: Ration with inclusion of $15 \%$ of palm oil cake; T3: Ration with inclusion of $20 \%$ of palm oil cake. Palm oil cake was acquired from a local agricultural business, DENTAUA - Dendê do Tauá S/A, located at a Santo Antonio do Tauá, a City located in Pará State. Palm oil cake is obtained after breaking the nut of the palm fruit, where the nut is transformed into a mass by the addition of water and cooking in the digester, the mass is grinded to obtain the palm oil and the palm oil cake. Birds were allowed ad libtum access to feed and water.

Table 1. Composition and calculated value (\%) of the experimental diets for the starter phase of slow growing chickens (1-28 days), with inclusion of palm oil cake according to treatments

\begin{tabular}{lcccc}
\multicolumn{1}{c}{ Ingredients (\%) } & \multicolumn{2}{c}{ Treatments $^{1}$} & T1 & T2 \\
\hline Corn $\left(7.88 \% \mathrm{CP}^{*}\right)$ & $\mathrm{T} 0$ & 58.30 & 50.80 & 43.30 \\
Soybean Meal (45\% CP*) & 62.50 & 30.47 & 26.66 & 22.87 \\
Dicalcium Phosphate $\left(23 \% \mathrm{Ca} / 18 \% \mathrm{P}^{*}\right)$ & 32.37 & 1.41 & 1.37 & 1.33 \\
Limestone (38\%Ca*) & 1.43 & 1.00 & 1.01 & 1.02 \\
Soy Oil (EM 8.790kcal/kg*) & 1.00 & 2.05 & 3.26 & 4.47 \\
Common Salt & 1.44 & 0.47 & 0.47 & 0.47 \\
BHT & 0.48 & 0.10 & 0.10 & 0.10 \\
L-Lysine HCL (78\%) & 0.10 & 0.42 & 0.50 & 0.58 \\
DL-Methionine (99\%) & 0.37 & 0.16 & 0.18 & 0.19 \\
L-Threonine (98\%) & 0.16 & 0.08 & 0.11 & 0.14 \\
Palm oil cake & 0.07 & 10.00 & 15.00 & 20.00 \\
Starter Phase Premix ${ }^{2}$ & -- & 0.60 & 0.60 & 0.60 \\
\hline TOTAL & 0.60 & 100.0 & 100.0 & 100.0 \\
\hline
\end{tabular}

\begin{tabular}{lcccc}
\multicolumn{1}{c}{ Nutrients } & & & \\
\cline { 2 - 5 } & $\mathrm{T}$ & $\mathrm{T}$ & $\mathrm{T} 2$ & $\mathrm{~T}$ \\
\hline AMEn (Mcal/kg) & 2,980 & 2,980 & 2,980 & 2,980 \\
Crude Protein (\%) & 20.0 & 20.0 & 20.0 & 20.0 \\
Calcium (\%) & 0.86 & 0.86 & 0.86 & 0.86 \\
Available Phosphorus (\%) & 0.38 & 0.38 & 0.38 & 0.38 \\
Sodium (\%) & 0.21 & 0.21 & 0.21 & 0.21 \\
Ether Extract (\%) & 4.56 & 5.29 & 7.39 & 9.49 \\
Crude Fiber (\%) & 2.83 & 3.29 & 4.31 & 5.33 \\
Total Lysine (\%) & 1.34 & 1.34 & 1.34 & 1.34 \\
Met+ Cystine Total (\%) & 0.93 & 0.93 & 0.93 & 0.93 \\
Total Threonine (\%) & 0.85 & 0.85 & 0.85 & 0.85 \\
\hline
\end{tabular}

${ }^{*} \mathrm{CP}=$ Crude Protein; $\mathrm{Ca}=$ Calcium; $\mathrm{P}=$ Phosphorus; $\mathrm{ME}=$ Metabolizable Energy. ${ }^{1} \mathrm{~T} 0$ : Control Ration; $\mathrm{T} 1$ : Ration containing $10 \%$ of palm oil cake; T2: Ration containing $15 \%$ of palm oil cake; T3: Ration containing $20 \%$ of palm oil cake. ${ }^{2}$ Minimal composition per kilo of the product: Vitamin A 1,333,333.00UI; Vitamin B1 166mg; Vitamin B12 1,666 $\mu$; Vitamin B2 666mg; Vitamin B6 166mg; Vitamin D3 300,000.00 UI; Vitamin E 2,000.00UI; Vitamin K3 333mg; Biotin 6mg; Choline 36g; Niacin 4,666mg; Folic Acid 67mg; Pantothenic Acid 1,717mg; Cobalt 16mg; Copper 1,000mg; Iron 8,333mg; Iodine 166mg; Manganese 10.83g; Selenium 33mg; Zinc 7,500mg; Methionine 233.33g; Bacillus subtilis 50,000000000 UFC; Halquinol 5,000mg; Salinomycin $10,99 \mathrm{~g}$

\section{Measurements}

At the beginning of the experiment (day one), all birds were individually weighed, average was $38.86 \mathrm{~g} \pm 0.11 \mathrm{~g}$. Data regarding the birds' weight, feed intake, and mortality rates were obtained on a weekly basis from each experimental pen, and used for the evaluation of the broilers' performance. At the end of the experiment, two birds from each replicate were chosen according to the average weight of the pen, identified, and fasted for a period of eight hours, then slaughtered by manual cervical dislocation. For the allometry of organs, the following organs of the digestive system were measured and weighed: length of the gastrointestinal tract (GI Tract) in centimeters $(\mathrm{cm})$, measured from the insertion of the esophagus in the oropharynx until the connection of the large intestine with the cloaca; weight in grams (g) of esophagus plus crop, proventriculus, 
gizzard, and small intestine plus large intestine. With those measurements, the absolute weight $(\mathrm{g})$ and relative weight $(\%)$ of the organs was determined, calculated by the percentage of live weight of the birds at slaughter.

\section{Statistical Analyses}

The results obtained were initially submitted to the normality test (Shapiro-Wilk) and, for the normal variables to the analysis of variance (ANOVA), the treatment means were compared by the Tukey test up to 5\% probability, using the SAS University Edition (2016).

Based on the performance data, feed cost, and acquisition of chicks, the following indices were computed (Espindola, 2011): Effective Operational Cost (EOC); Gross Revenue (GR); Gross Margin in relation to Effective Operational Cost (GMEOC), Break Even Point (BEP), Operating Profit (OP), and Profitability Index (PI). The means were analyzed, and compared using Tukey test (0.05 level of probability).

\section{Results and Discussion}

No effects from the different levels of palm oil cake (POC) included were observed on broiler initial weight, body weight gain (BWG) and feasibility $(\mathrm{p}>0.05)$ (Table2).

Feed intake (FI) was influenced by the levels of inclusion of palm oil cake $(\mathrm{p}<0.05)$. The dietary treatment which had inclusion of $10 \%$ $(\mathrm{FI}=1.066 \mathrm{~g})$ of palm oil cake was statistically equal to control treatment with no inclusion (lower FI=1.011g) and to treatments which had 15 ( $\mathrm{FI}=1.091)$ and $20 \%(\mathrm{FI}=1.095 \mathrm{~g})$ of inclusion of palm oil cake. Feed conversion (FC) was also affected by the levels of palm oil cake $(\mathrm{p}<0.05)$, the best FC was observed in the control treatment (1.484) and it was statistically equal to the treatments of $10 \%$ (1.552) and 15\% (1.534) of inclusion of palm oil cake, birds that received the diet with $20 \%$ of inclusion had the lower FC (1.643) (Table 2).

Table 2. Average of the performance parameters according to the amount (\%) of palm oil cake in the diet of slow growing chickens over the starter phase (1-28 days) per treatment ${ }^{1}$

\begin{tabular}{llcccc}
\hline \multicolumn{1}{c}{ Parameters } & T0 & T1 & T2 & T3 & CV (\%) \\
\hline \multicolumn{7}{c}{ Starter Phase $(1-28$ days) } & & \\
\hline Initial Weight (g) & 38.27 & 38.13 & 38.22 & 38.11 & $3.15^{\text {ns }}$ \\
Weight Gain (g) & 682.3 & 687.5 & 711.8 & 668.0 & $5.02^{\text {ns }}$ \\
Feed Intake (g) & $1.011^{\mathrm{b}}$ & $1.066^{\mathrm{ab}}$ & $1.091^{\mathrm{a}}$ & $1.095^{\mathrm{a}}$ & $5.29^{*}$ \\
Feed Conversion & $1.484^{\mathrm{b}}$ & $1.552^{\mathrm{ab}}$ & $1.534^{\mathrm{ab}}$ & $1.643^{\mathrm{a}}$ & $6.37^{*}$ \\
Feasibility (\%) & 96.15 & 96.15 & 97.11 & 95.19 & $8.78^{\mathrm{ns}}$ \\
\hline
\end{tabular}

${ }^{1}$ T0: Control ration without palm oil cake; T2: Ration containing 10\% of palm oil cake; T3: Ration containing 15\% of palm oil

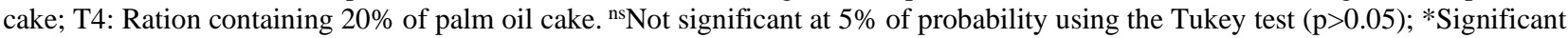
at $5 \%$ of probability using the Tukey test $(\mathrm{p}<0.05)$. **Significant at $1 \%$ of probability using the Tukey test $(\mathrm{p}<0.01)$. Means followed by the same letters do not differ statistically among each other using the Tukey test $(5 \%)$.

Results of studies on the performance of fast growing chickens fed with palm oil cake are contradictory. Ezieshi and Olomu (2008) reported a decrease in the body weight gain of fast growing chickens fed with diets that had $30 \%$ of inclusion of this ingredient. On the other hand, Abdollahi et al. (2016), who studied birds until 21 days of rearing, reported similar results to ours; they reported that $10 \%$ of palm oil cake in the ration did not affect the body weight gain of fast growing chickens until 28 days of rearing regardless of adding enzyme in the feed.

An unexpected increase was observed in the FI of the birds that had $20 \%$ of the ingredient in the diet. This fact may be related to the increase in the rate of passage of food in the digestive tract of the birds, and also an expression of the need for the animals to consume sufficient amount to meet their energy requirement, since with the increase in the levels of POC the energy of the diet is diluted (Shakila et al., 2012; Adbollahi et al., 2016). Another factor that possibly influenced the increase in FI was the addition of soybean oil to balance diets with higher levels of inclusion of POC, stimulating consumption by chickens.

There was a negative effect of the inclusion of POC in the diet on the FC, result previously expected because there was no effect on the body weight gain; however, there was an effect on the FI that made the birds that received higher levels of POC reflected with worse FC, and the level of $20 \%$ of POC with the highest index (1.643). Currently, there are no data available in the literature for slow growing chickens in the initial phase (1-28 days); most of the published studies were carried out with these birds in the growth 
phase until fattening and slaughter, where, based on the extensive breeding system, birds have access to a free area and may vary their food ingestion according to what they find in the grass, such as fodder, small insects, larvae and pebbles. However, it is essential to know the growth pattern and behavior of slow-growing broilers in order to adjust their nutritional management and feed requirement appropriately for each breeding phase (Morais et al., 2015).

There was no effect of the POC at slaughter weight, length of the GI tract, relative weight of esophagus plus crop, proventriculus and intestine $(p>0.05)$ (Table 3). Just the relative weight of the gizzard had a significant effect $(\mathrm{p}<0.01)$, in which the inclusion of 15 and $20 \%$ of POC promoted higher values (3.68 and 3.75\%). The increase in fiber in the diet stimulated the gizzard's muscle activity, which can be caused by the increase in the food retention time, or by the presence of particles of different sizes that require greater crushing, increasing movement and causing organ hypertrophy, similar results to our study were reported by Esposito et al. (2015) and Frank et al. (2016). Hernández et al. (2011) in a study on the content of soluble fibers present in the food, infer that they can increase the liquid retention capacity, resulting in the dilation of the content and consequently increasing the volume of the gizzard.

Table 3. Slaughter weight, length of GI Tract and relative weight of organs (\%) of the digestive system of slowgrowing chickens fed with palm oil cake (1-28 days), per treatment ${ }^{1}$

\begin{tabular}{|c|c|c|c|c|c|}
\hline Parameters & T0 & T1 & $\mathrm{T} 2$ & T3 & CV (\%) \\
\hline \multicolumn{6}{|c|}{ Starter Phase (1-28 days) } \\
\hline Slaughter weight (g) & 709.37 & 710.42 & 712.50 & 697.75 & $5.96^{\mathrm{ns}}$ \\
\hline $\operatorname{GIT}(\mathrm{cm})$ & 138.50 & 136.00 & 133.37 & 140.12 & $8.19^{\text {ns }}$ \\
\hline Esophagus + Crop (\%) & 0.30 & 0.34 & 0.33 & 0.36 & $15.47^{\mathrm{ns}}$ \\
\hline Proventriculus $(\%)$ & 0.55 & 0.52 & 0.56 & 0.57 & $13.09^{\mathrm{ns}}$ \\
\hline Gizzard $(\%)$ & $3.05^{b}$ & $3.30^{\mathrm{ab}}$ & $3.68^{\mathrm{a}}$ & $3.75^{\mathrm{a}}$ & $11.96^{*}$ \\
\hline Intestine $(\%)$ & 3.81 & 3.51 & 3.94 & 4.01 & $12.67^{\mathrm{ns}}$ \\
\hline
\end{tabular}

${ }^{1}$ T0: Control ration without palm oil cake; T2: Ration containing 10\% of palm oil cake; T3: Ration containing $15 \%$ of palm oil cake;

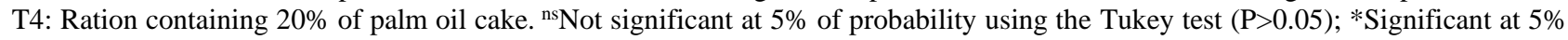
of probability using the Tukey test $(\mathrm{p}<0.05)$. Means followed by the same letters do not differ statistically among each other using the Tukey test.

In this trial, POC did not promote a negative effect on body weight gain in slowgrowing broilers, however, it promoted an increase in FI and decreasing FC at the highest levels, it is essential to analyze the economic viability of the rations to help the producer when deciding to include it or not in the nutritional management of its creation. The cost related to the rations $(\mathrm{R} \$ / \mathrm{Kg})$ according to the selling price of the ingredients in the Metropolitan area of Belem (March of 2016 as reference) and the feed cost are presented in the Table 4.

Table 4. Production performance and production cost of slow-growth broilers in the initial growth phase ( 1 to 28 days) fed with diet containing different proportions of Palm Oil Cake. Production cost values are form March 2016. All monetary values are in Brazilian real ( $R \$)$.

\begin{tabular}{lcccc}
\hline \multirow{2}{*}{ Starter Phase (1 a 28dias) } & \multicolumn{3}{c}{ Teatments $^{1}$} \\
\cline { 2 - 5 } & $\mathrm{T} 0$ & $\mathrm{~T} 1$ & $\mathrm{~T} 2$ & $\mathrm{~T} 3$ \\
\hline Starter Ration $(\mathrm{R} \$ / \mathrm{kg})$ & 1.599 & 1.585 & 1.577 & 1.574 \\
Feed Intake $(\mathrm{kg})$ & 1.011 & 1.067 & 1.091 & 1.095 \\
Cost / phase $(\mathrm{R} \$ /$ chicken) & 1.616 & 1.691 & 1.720 & 1.723 \\
N of birds /treatment & 100 & 100 & 101 & 99 \\
Average weight $(\mathrm{kg})$ & 0.721 & 0.726 & 0.750 & 0.706 \\
Cost per kilo of chicken $(\mathrm{R} \$ / \mathrm{kg})$ & 2.241 & 2.329 & 2.316 & 2.416 \\
\hline
\end{tabular}

${ }^{1}$ T0: Control ration without palm oil cake; T2: Ration containing 10\% of palm oil cake; T3: Ration containing 15\% of palm oil cake; T4: Ration containing $20 \%$ of palm oil cake.

The rations with inclusion of palm oil cake had a lower cost than the control ration, in which the inclusion of $20 \%$ of the ingredient in the diet promoted a decrease of the price per kilo in $1.56 \%$ compared to the control diet cost. The feed intake was $8.30 \%$ higher in birds that received the diet containing $20 \%$ of palm oil cake than birds of the control diet. The birds fed the ration with the 
highest level of palm oil cake (20\%) had an average weight $2.08 \%$ lower than birds fed with control ration, which resulted in a more expensive diet. As such, adding 10,15 , and $20 \%$ in rations increased the cost by $3.92,3.34$, and $7.80 \%$ respectively. Table 5 shows the feasibility and economic indicators in the production of slow growing broiler chickens.

Table 5. Operating Cost (OC), Gross Revenue, Gross Margin (GM), Break Even Point (BEP), Operating Profit (OP), and Profitability Index (PI) for the production of one experimental unit of slow-growing broilers over the initial phase (1-28 days), separated by treatment.

\begin{tabular}{lccccc} 
& \multirow{2}{*}{ Phase } & \multicolumn{3}{c}{ Treatments $^{1}$} & \multirow{2}{*}{ CV\% } \\
\cline { 2 - 5 } & $\mathrm{T} 0$ & $\mathrm{~T} 1$ & $\mathrm{~T} 2$ & $\mathrm{~T} 3$ & \\
\hline $\mathrm{OC}^{2}(\mathrm{R} \$ / 13$ broilers $)$ & 63.89 & 64.84 & 65.25 & 65.28 & $1.78^{\mathrm{ns}}$ \\
$\mathrm{GR}^{3}(\mathrm{R} \$)$ & 90.06 & 90.66 & 94.66 & 87.16 & $9.00^{\mathrm{ns}}$ \\
$\mathrm{GM}^{4}(\%)$ & 40.99 & 39.94 & 45.13 & 33.83 & $34.01^{\mathrm{ns}}$ \\
$\mathrm{BEP}^{5}(\mathrm{~kg})$ & 6.38 & 6.48 & 6.52 & 6.53 & $1.77^{\mathrm{ns}}$ \\
$\mathrm{OP}^{6}(\mathrm{R} \$)$ & 26.17 & 25.82 & 29.41 & 21.89 & $33.81^{\mathrm{ns}}$ \\
$\mathrm{PI}^{7}(\%)$ & 28.70 & 28.22 & 30.77 & 23.18 & $32.99^{\mathrm{ns}}$ \\
\hline
\end{tabular}

${ }^{1}$ T0: Control ration without palm oil cake; T2: Ration with 10\% of palm oil cake; T3: Ration with 15\% of palm oil cake; T4: Ration with $20 \%$ of palm oil cake. ${ }^{2}$ Sum of the cost for ration + fixed cost + chick cost $(\mathrm{R} \$ 2.50) \times 13$ chickens. ${ }^{3}$ Average weight $\mathrm{x} n$. birds sold $x$ R $\$ 10.00 / \mathrm{kg}$ live weight. ${ }^{4}$ (GR-OC)/OC*100. ${ }^{5} \mathrm{OC} /$ Selling price. ${ }^{6} \mathrm{OP}=$ GR-OC. ${ }^{7} \mathrm{PI}=\mathrm{OP} / \mathrm{GR}{ }^{\text {ns }}$ Not significant at $5 \%$ of probability using the Tukey test $(\mathrm{P}>0.05)$; *Significant at $5 \%$ of probability using the Tukey test $(\mathrm{p}<0.05)$. Means followed by the same letters do not differ statistically among each other using the Tukey test.

The POC did not influence any of the economic parameters under the conditions of this research ( $\mathrm{p}>0.05)$. In spite of giving a feed at a slightly higher cost than traditional ingredients, the use of palm oil cake in slow growing chickens can be an economically feasible solution in periods of scarcity of traditional ingredients or over the off-season, since it will not have a negative effect on the profit of the farmer.

\section{Conclusion}

The palm oil cake can be included in diets for slow-growing chickens, up to 28 days, without any prejudice to the performance, allometry of the digestive organs, or economic disadvantage, being the inclusion of $15 \%$ the one which provided the best results.

\section{Conflict of Interest}

The authors declare that they have no conflict of interest.

\section{Ethics Committee}

This study was carried out in accordance with the recommendations of the Institutional Animal Care and Use Committee of the Federal Rural University of the Amazon and the Federal Council of Veterinary Medicine Resolution $\mathrm{n}$ 1.000/CFMV (CFMV, 2012). The protocol was approved by the Institutional Animal Care and Use Committee of the same University (CEUA/UFRA, protocol n 027/2014). All efforts were made to minimize the birds' suffering.

\section{Acknowledgments}

This research is part of the doctoral thesis of the first author and was supported by the Amazonian Paraense Foundation of Support for Studies and Research - Fapespa.

\section{References}

Abdollahi, M.R.; Hosking, B.J., Ning, D., Ravindran, V. Influence of palm kernel meal inclusion and exogenous enzyme supplementation on growth performance, energy utilization, and nutrient digestibility in young broilers. Asian and Australians Journal of Animal Science, 29(4): 539-548, 2016.

Albino, L.F.T.; Nery, L.R.; de Vargas Júnior, J.G.; da Silva, J.H.V. Criação de frango e galinha caipira: avicultura alternativa. Viçosa: Aprenda Fácil, 2005. 46p.

Braga, R.M.; Roque, M.S. Comercialização de galinha viva do tipo "caipira" em Boa Vista, Roraima. Roraima: Centro de Pesquisa Agroflorestal de Roraima, 2008. $24 \mathrm{p}$.

Bringel, L.M.L.; Neiva, J.N.M.; Araujo, V.L.; Bonfim, M.AD.; Restle, J.; Ferreira, A.C.H.; Lôbo, R.N.B. Consumo, digestibilidade e balanço de nitrogênio em borregos alimentados com torta de dendê em substituição à silagem de capim-elefante, Revista Brasileira de Zootecnia, 40(9): 1975-1983, 2011. 
Brum, O.B.; Rosa, A.P.; Stefanello, C.; Dias, E.R.; Uttpatel, R. Efeito do cruzamento de diferentes genótipos para usos em sistemas alternativos de frango de corte. Acta Scientiarum Animal Science, 32(2): 183$187,2010$.

Camelo, L.C.L.; Lana, G.R.Q.; Santos, M.J.B.; Camelo, Y.A.R.P.; Marinho, A.L.; Rabello, C.B.V. Inclusão de farelo de goiaba na dieta de codornas europeias. Ciência Animal Brasileira, 16: 343-349, 2015.

Correia, B.R.; Oliveira, R.L.; Jaeger, S.M.P.L.; Bagaldo, A.R.; Carvalho, G.G.P.; Oliveira, G.J.C.; Lima, F.H.S.: Oliveira, P.A. Consumo, digestibilidade e $\mathrm{pH}$ ruminal de novilhos submetidos a dietas com tortas oriundas da produção do biodiesel em substituição ao farelo de soja. Arquivo Brasileiro de Medicina Veterinária e Zootecnia, 63(2): 356-363, 2011.

Cunha, O.F.R.; Neiva, J.N.M.; Maciel, R.P.; Miotto, F.R.C.: Neiva, A.C.G.R. Avaliação Bioeconômica do uso da torta de dendê na alimentação de vacas leiteiras. Ciência Animal Brasileira, 13(3): 315-322, 2012.

CFMV - Conselho Federal de Medicina Veterinária. Manual de Legislação do Sistema CFMV/CRMV's. Resolução n'1000, de 11 de maio de 2012. <http://portal.cfmv.gov.br/portal/lei/index/id/ 326>. Accessed in 30 Apr. 2016.

Espíndola, G.B. Revisão dos parâmetros não zootécnicos aplicados em nutrição de monogástricos. Fortaleza: Expressão Gráfica e Editora, 2011. v.1, 178p.

Espósito, M.; Fassani, É.J.; Clemente, A.H.S.; Makiyama, L.; Retes, P.L.; de Faria Castro, $\mathrm{S}$. Uso da cana de açúcar triturada na alimentação de frangos de corte tipo caipira. Boletim de Indústria Animal, 72(2): 129136, 2015.

Ezieshi, E.V.; J.M. Olomu. Nutritional evaluation of palm kernel meal types: 2 Effects on liver performance and nutrient retention in broiler chicken diets. African Journal of Biotechnology, 7: 1171-1175, 2008.

Fernandes, R.T.V.; Vasconcelos, N.V.B.; Lopes, F.F.; Arruda, M.V. Aspectos gerais sobre alimentos alternativos na nutrição de aves. Revista Verde de Agroecologia e Desenvolvimento Sustentável, 7(5): 66-72, 2012.
Frank, R.; Nunes, R.V.; Schone, R.A.; Parra, A.P.; Castilha, L.D. Performance and intestinal parameters of Label Rouge chickens fed on high-moisture corn silage. Revista Ciência Agronômica, 47(4): 761-769, 2016.

Guéguen, L.; Pascal, G. Le point sur la valeur nutritionnelle et sanitaire des aliments issus de l'agriculture biologique. Cahiers de Nutrition et de Dietetique, 45: 130-143, 2010

Hernández, F.; López, M.J.; García, V.; Martínez, S.; Megías, M.D.; Madrid, J. Influence of cereal type and the inclusion of sunflower meal as a source of additional dietary fiber on nutrient retention, growth performance and digestive organ size in broilers from one to twenty-one days of age. Animal Feed Science and Technology, 165: 251-257, 2011.

Morais, J.; Ferreira, P.B.; Jacome, I.M.T.D.; Mello, R.; Breda, F.C.; Rorato, P.R.N. Curva de crescimento de diferentes linhagens de frango de corte caipira. Ciência Rural, 45: 1872-1878, 2015.

Nahashon, S.N.; Aggrey, S.E.; Adefope, N.A.; Amenyenu, A.; Wright, D. Gompertz-Laird model prediction of optimum utilization of crude protein and metabolizable energy by French guinea fowl broilers. Poultry Science, 89: 52-57, 2010.

Nöel, J.M. Products and by-products. Montpellier: Burotrop Bulletin, 2003. v.1, 8p. Nunes, A.S.; Oliveira, R.L.; Borja, M.S.; Bagaldo, A.R.; Macome, F.M. Consumo, digestibilidade e parâmetros sanguíneos de cordeiros submetidos a dietas com torta de dendê. Archivos de Zootecnia, 60(232): 903-912, 2011.

Nunes, J.K., Gentilini, F.P., Anciuti, M.A., and Rutz, F. Alimentos alternativos ao milho na dieta de aves. Revista Eletrônica Nutritime, Viçosa, MG, 10(4): 2627-2645, 2013.

Rostagno, H.S.; Albino, L.F.T.; Donzele, J.L.; Gomes, P.C.; Oliveira, R.F.; Lopes, D.C.; Ferreira, A.S.; Barreto, S.L.T.; Euclides, R.F. Tabelas brasileiras para aves e suínos. Viçosa: Universidade Federal de Viçosa, 2011. v.1, 252p.

SAS Institute Inc. SAS ${ }^{\circledR}$ University Edition: installation guide for windows. Cary, NC: SAS Institute Inc. 2016.

Santos, J.F.; Granjeiro, J.I.T. Desempenho de aves caipira de corte alimentadas com mandioca e 
palma forrageira enriquecidas com levedura. Tecnologia \& Ciência Agropecuária, 6(2): 49-54, 2012.

Silva, H.G.O.; Pires, A.J.V.; Silva, F.F.; Veloso, C.M.; Carvalho, G.G.P. Farelo de cacau (Theobroma cacau) e torta de dendê (Elaeisguineensis, jacq) na alimentação de cabras em lactação, consumo e produção de leite. Revista Brasileira de Zootecnia, 34(5): 1786-1794, 2005.

Sousa, J.P.L.; Santos Neta, E.R.; Maciel, R.P.; de Sousa, J.T.L.; Rodrigues, K.F.; Vaz, R.G.M.V. Uso da torta de dendê em dietas para animais de produção. Pubvet, 4(6): 112, 2010.

Shakila, S.; Sudhakara Reddy, P.; Reddy, P.V.V.S.; Ramana, J.V.; Ravi, A. Effect of palm kernel meal on the performance of broilers. Tamilnadu Journal of Veterinary \& Animal Sciences, 8(4): 227-234, 2012.

Zanusso, J.T.; Dionello, N.J.L. Produção avícola alternativa - Análise dos fatores qualitativos da carne de frangos de corte tipo caipira. Revista Brasileira Agrociência, 9(3): 191194, 2003. 